\title{
THE EFFECTS OF INNOVATION ON MARKET COMPETITION: THE CASE OF THE INSURANCE COMPARISON WEBSITES
}

\begin{abstract}
In the insurance market, the use of digital technologies facilitating online transactions is increasing together with the diffusion of the so called comparison websites. Taking into account this fact, the first issue addressed by this article is the analysis of the process of digitalization of the distributional channels both in life and non-life sectors in the European countries. Given the use of different channels, such as brokers, agents and bancassurance, a particular role is played by the comparison website. The second issue is to look at the regulatory interventions at the European level. These interventions mainly promote the adoption of behaviours that ensure the correctness of the comparison and the transparency of the information made available to the public through online platform. In this direction, the author investigates particularly the Italian case and the intervention of the insurance supervisory Authority and of the national Antitrust Authority. Moreover, the article contribution to the literature is to examine the effects of the comparison website on market competition: the effects are described, on one hand, as positive in terms of decreasing asymmetric information suffered by the insured, on the other hand, as negative in terms of increasing the possibility of collusive behaviours by the insurance companies. To confirm this last point a decision by the Lithuanian Antitrust Authority, confirmed by the European Court of Justice, is quoted to show how an online platform can be an information exchange tool and its behaviour can be considered as a facilitating practice to support collusion. The purpose of the analysis proposed is to provide useful elements for the future regulatory interventions that will follow the diffusion of new distributional channels in the insurance market. Particularly, the growing diffusion of comparison websites will involve the adoption of regulatory instruments aimed not only at protecting consumers but also at limiting their use as tools for collusive behaviour.
\end{abstract}

Keywords: Insurance market, comparison websites, regulation, competition.

Introduction. In the wake of the markets characterized by high volumes of commercial exchanges, even in the financial ones, and in particular in the insurance market, the use of technologies that facilitate online transactions is increasingly widespread. And among the emerging new instruments, the so-called comparison websites are increasingly spreading: this is the case of web platforms that allow consumers to obtain estimates relating to a particular policy and eventually enter into the contract directly, constituting in this case a distribution channel of the insurance supply.

Therefore, from the point of view of the demand, the comparison websites are aimed at the new generation of consumers who are characterized by being always connected; from the point of view of the supply, they are inserted in an evolutionary context, in which the companies have started a process of digital renewal of the traditional distributional models.

Recently, the English Competition \& Market Authority in the Digital comparison tools market study (2017) provided that: "Digital Comparison Tools (DCTs) play a major role in a variety of markets, and many consumers use them to shop around. They offer substantial benefits in reducing hassle for people and in increasing competition. For those benefits to be maximised, a number of conditions need to be met: consumers need to be confident enough and have enough trust to use DCTs; DCTs themselves need the ability to operate effectively; competition needs to be effective; and regulation of DCTs needs to be appropriate". 
Generally, in regulatory interventions, there is a great deal of attention to the protection of customers who make purchasing choices based on the comparison that sites propose. But, on the other hand, another relevant issue is the analysis of the effects on market competition.

In this regard, in the next section the digitization of the distribution channels will be analysed; hereafter, the comparison websites and the recent interventions of the European Authorities will be defined; the positive impact of the comparison websites on the competitiveness of the insurance market will be examined and, finally, the negative impact that may derive in particular from collusive practices.

The digitalization of the insurance distribution. The effects of the digitalization process are strictly connected with the characteristics of the distributional channels of the markets.

Insurance is sold either directly by insurance companies or through a number of other channels, the most common of which are brokers, agents and bancassurance. The popularity of each channel varies depending on both the market and the insurance product. This diversity of channels, which makes possible for insurers to adjust to different cultures, needs and preferences in different markets, is in the interest of consumers.

In Figures 1 and 2, we see the differences in the distributional channels between the European countries in the Life and Non-Life insurance sectors as a percentage of gross written premiums (GWP).

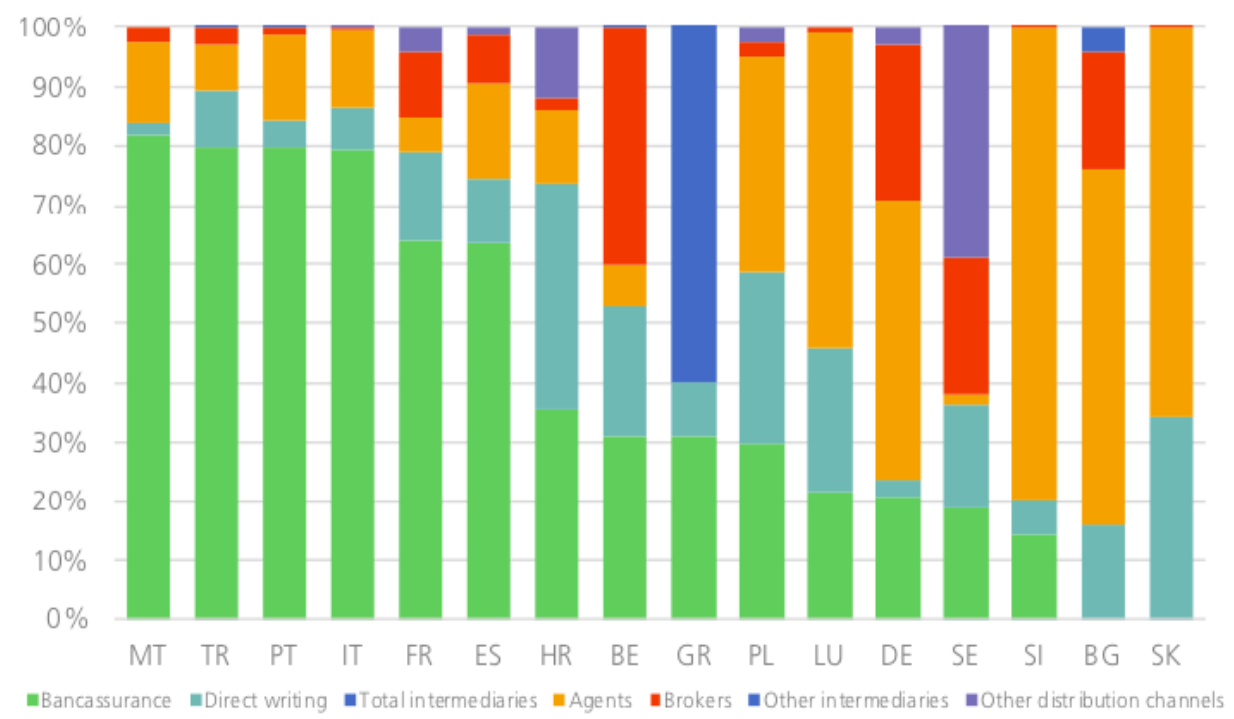

Figure 1 - Life distribution channels in 2015, \% of GWP (Insurance Europe, 2017, p. 46)

Among the largest life insurance markets, most products were sold via bancassurance in Italy $(79 \%$ of gross written premiums in 2015) and France and Spain (64\% each), while in the UK most life products were sold by agents and brokers (68\%). The other European markets, in which bancassurance was most dominant, were Malta (82\%), Portugal and Turkey (80\% in each).

The market, in which agents and brokers were most dominant, was Bulgaria $(80 \%)$. Agents alone were the main distribution channel in Slovenia (80\%) and Slovakia (66\%). 


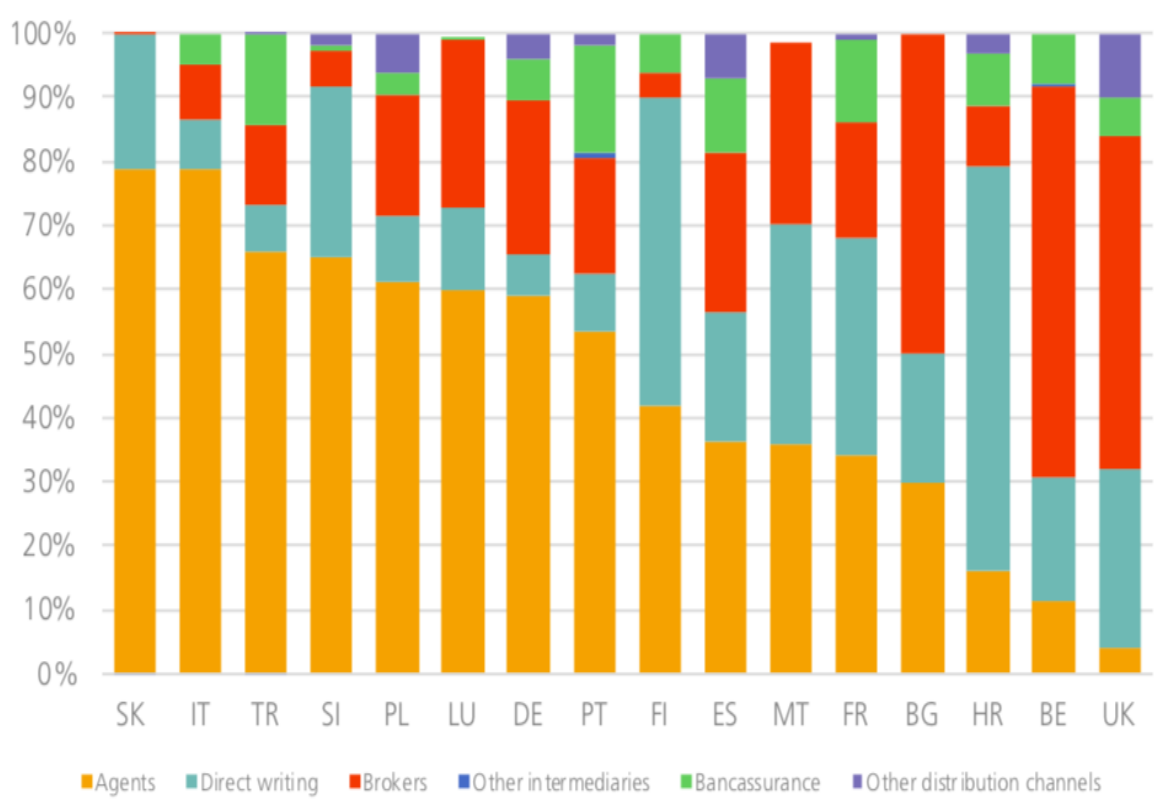

Figure 2 - Non-Life distribution channels in 2015, \% of GWP (Insurance Europe, 2017, p. 47)

In both large and small markets, non-life insurance policies are mainly distributed through agents and brokers.

Agents predominate in Italy $(79 \%)$, Slovakia $(79 \%)$, Turkey $(66 \%)$, Slovenia $(65 \%)$, Poland $(61 \%)$, Germany (59\%) and Portugal (54\%). Meanwhile, brokers account for $61 \%$ of non-life premiums in Belgium, $52 \%$ in the UK and $50 \%$ in Bulgaria.

In contrast, Croatia had the largest proportion of non-life products sold directly (63\%), followed by Finland (48\%), France and Malta (34\% each).

Generally, we can say that over the past years traditional intermediaries in the insurance market have faced challenging conditions as innovation have altered the competitive landscape. The agency channel has lost significance in most European markets (the Italian non-life segment is a notable exception to this general trend). The broker channel has been stable or has typically lost share, particularly in non-life (the Dutch life market is an exception to this). However, there has been some cannibalization, notably in the UK and the Netherlands, where comparison websites have gained at the expense of traditional brokers.

In fact, comparison websites facilitate the comparison of price reducing search costs for most consumers and hence the value of those distributional channels that focus upon performing this economic function. This means that brokers can more easily be substituted, especially the smaller ones or those that do not offer high-quality services.

Comparison websites, as aggregators of different insurance companies, have enabled self-directed consumers to fulfil more processes independently, that is easier for standardized products (such as in motor-vehicle sector) than complex ones (such as in life sector), but is not restricted to the former. This is a process that drives to a greater polarization between a price-focus system and a quality focus one (Brown and Goolsbee, 2002).

So, the direct channel has experienced notable declines in France, Italy and Spain. Indeed, bancassurance (or at least the use of banks as a distributional channel even where the bank is structurally separate from the insurer) has been a major trend in itself. Gains in the direct channel in the UK and Dutch 
non-life markets, on the other hand, highlight the growth of remote direct selling, initially by phone and then through the internet.

Where change has occurred, its main drivers have been technological dynamic but also regulatory innovation. For example, the growth of banks as an important distributional channel in the life segment, particularly evident in France, Italy and Spain, was driven by liberalising legislation in the context of markets lacking an effective alternative.

The regulatory challenge. The change in terms of digitalization, analysed in the above section, involves a special focus in terms of regulation and in this context arises the new European Directive on Insurance Distribution (IDD), that has already triggered a process of public consultation in all European countries and among all stakeholders.

The IDD came into force on 22 February 2016 and updates the 2002 Insurance Mediation Directive (IMD), which set out a framework for regulating EU insurance brokers, agents and other intermediaries. Member states have two years to transpose the IDD into national laws and regulations, i.e. before 23 February 2018 on which date it will replace the IMD.

As a directive, the IDD provides a "minimum harmonising" regulation and member states will be able to "gold-plate" it by adding extra requirements in the implementation. In any case, the IDD is intended to significantly raise the minimum standards of the IMD.

Where the existing IMD applies to the regulation of insurance intermediaries, the new IDD applies to the wider regulation of insurance "distributors". This means that it applies to all sellers of insurance products, including insurance undertakings that sell directly to customers: currently, the IMD applies to insurance intermediaries only. However, in order to level the market between direct and intermediated sales, the new directive applies to all sellers of insurance products including those that sell directly to customers.

The Directive confirms that insurance distribution takes place when websites or other media are used to provide information about insurance contracts in accordance with criteria selected by customers and there is a compilation of an insurance product ranking list, including price and product comparison, or a discount on the price of an insurance contract, and when the customer is able to directly or indirectly conclude an insurance contract using that website or other media.

The comparison sites are in general a phenomenon under observation by the Authorities and, in this direction, the EIOPA was the first to take action with the publication in 2014 of the Report on Good Practices on Comparison Websites.

The Report aims to establish good practices in the use of comparison websites, based on the principles of transparency, simplicity and correctness for Internet users on the basis of the results of a previously conducted survey; in practice, it provides indications, with no binding force, which constitute a sort of complementary guide to European and national legislation.

In the Report, once the main characteristics and the different business models of the comparison websites have been identified, the good practices are listed with reference to the areas that presented the most critical issues in the survey, such as: the information relating to the website; the scope of products and producers taken into consideration in the market; the management of potential conflicts of interest; the comparison criteria used for the classification of products; the presentation of information; the frequency of updating information.

To the interest in comparison websites at European level, it corresponds the one at national level, for example in Italy the national insurance supervisory Authority, IVASS, conducted a survey on the comparison websites operating in the Italian insurance market aimed at verifying the level of transparency of the information provided to the public, the comparison criteria and the existence of possible conflicts of interest able to influence the result of the comparison, with the aim of protecting consumers. The survey (IVASS, 2014), which took into consideration six websites related to insurance intermediaries, reiterated 
the same problems highlighted in the EIOPA Report, finally arriving at prescribing some interventions to be carried out by the recipients and the publication of five recommendations for consumers, as follows:

1. The sites compare only (or predominantly) the products of few companies with which they have entered into agreements and from which they receive commissions in relation to each contract stipulated.

2. The number of companies compared is much lower than the total number of companies operating in the branch of automobile insurance. The only non-commercial site that compares all companies today is the public one managed by IVASS and MISE (called "tuopreventivatore").

3. The websites make extensive use of advertising messages formulated in such a way as to give consumers the conviction that they can obtain significant savings ("up to 500 euros") and purchase the "best product". They often claim to compare the "best" companies or the "best" products. However, they do not indicate the criteria for evaluating companies and products or the basis for calculating the promised savings.

4. The cheapest policy may not be the most appropriate for individual insurance needs. The comparison is based today exclusively on the price of the policy and does not take into account the contractual conditions, for example guarantee limits, deductibles, recourse rights, exclusions and limitations of coverage. Comparisons are made of products with different clauses such as, for example, the "exclusive driving" (which restricts driving to one driver) or "free drive" (which does not have this limitation). It is important to carefully evaluate whether the policies presented by the site are suitable for your needs.

5. It is common practice for sites to combine the motor-vehicle insurance with optional covers not requested by the consumer, forcing him to deselect them. This may be motivated by the fact that partner insurance companies generally recognize additional fees in the event of matching.

The IVASS "five recommendations" summarize the results of a survey with the aim to warn insurers about the limits of comparison websites. In correspondence with this, the Authority requires the examined websites to adopt specific corrective measures to remove critical points: for example, it is required to clearly indicate the list of companies with which there are partnership agreements and the payment of commissions; to publish the comparative market share, to compare only products with characteristics responding to the coverage needs expressed by the customer and not to base the comparison only on the price.

In Italy, the IVASS survey did not constitute an isolated intervention. In fact, in 2015 the Antitrust Authority (AGCM) made two decisions with respect to comparison websites, both concluded with binding commitments for the parties (PS9212 - FACILE.IT-COMPARATORE RC AUTO, Provvedimento n. 25420; PS9518 - 6SICURO.IT-COMPARATORE RC AUTO, Provvedimento n. 25421).

A first profile highlighted by the AGCM concerns the lack of transparency regarding the number and identity of the compared companies, the sales process and the sources of profit for the comparison websites. The risk is to generate a potential ambiguity with respect to the result of the comparison due to the presence of any interests of the site in guiding the consumer's choices towards some companies.

In particular, it was noted that it appears difficult to fully understand some aspects essential for the decision-making process of a consumer, and it is not clear the nature of the economic activity performed by the website (if it sells policies and if it is remunerated by all or some companies), the comparative scope of reference (number and identity of the companies, their representativeness and overall market share), the value of the result of the comparison, the characteristics of the sales process of the selected policies.

A second profile concerns the inclusion among the results of the comparison of optional insurance coverage with respect to the motor-vehicle insurance that the customers do not request, with the consequence of making the offers of companies not homogeneous and difficult to compare.

With regard to optional policies, the AGCM noted that the consumer makes his choice of purchase following the insertion of information, in the belief that the proposed policies have the required 
characteristics and that the order of convenience is based on prices of policies with homogeneous characteristics. If this does not happen, they are provided with policies with additional coverage or different from those required without giving adequate evidence.

With regard to this second profile, the companies have undertaken to propose insurance policies in line with the characteristics and requirements indicated by consumers, who may eventually select with a click the additional insurance coverage, expressing their will explicitly with the mechanism so-called optin.

Both cases decided by the AGCM ended with the acceptance of the commitments proposed by the parties.

In practice, the interventions analysed in this section focus on the need to impose transparency rules on sites to carry out their comparison function correctly and to be a useful tool for the consumer's choice of purchase.

In its decisions the AGCM, however, added another point regarding the benefit for consumers resulting from a quick and immediate comparison of the products of different companies, and so in a general benefit to the market functioning.

In this direction, the next section will analyse the consequences for competition that can derive from the comparison sites.

Digital comparison and competition. The comparison websites present several positive effects in terms of market competition: on the one hand, they can facilitate the knowledge of contracts and favour the solution of information asymmetries for consumers; on the other hand, they facilitate for competitors to enter the market contributing to a greater mobility (Parcu et al, 2016).

Under the first aspect, the companies are urged to limit the contractual differentiation only to some characteristics to make easier the comparison among contracts with a high level of homogeneity.

In practice, the offer of homogeneous policies not only reduces the problems associated with the choice of insurance products, but also allows a more complete understanding of what is provided in the policies, decreasing the negative consequences due to the information asymmetry for the customers (Marano, 2016).

So, comparison websites can be seen as intermediaries that simplify market operations and provide an economic advantage for both parts of the market: on the demand side, they substitute the research carried out in person, in which the insurers deal directly with every insurance companies; on the supply side, the companies can reach a larger number of potential clients without using the traditional distributional channels.

The European Commission in the Green paper on retail financial services. Better products, more choice, and greater opportunities for consumers and businesses identifies the comparison websites, together with the use of innovative digital technologies, as a useful channel to increase the cross-border business of companies, a fundamental and essential objective in the perspective of a single European market for retail financial services.

Specifically, the Green Paper provides: "Independent comparison sites can be helpful in ensuring that customers know that products exist, but their major benefit comes from the support they provide to consumers in switching, by allowing them to assess and choose between the most suitable products for their needs. EIOPA has found that comparison websites stimulate competition between insurers and insurance intermediaries and help enhance the transparency and comparability of information available to consumers" (European Commission, 2015a, p. 14).

As we have seen above, various factors indicate that the use of comparators in insurance choices may lead to greater competition in the market. From this, a reduction of prices in the market should be achieved and this effect would be particularly important for the Italian insurance market which, in the branch motor-vehicle policies, presents a particularly high level of premiums. 
In this direction, in another document the European Commission (2015b, pp. 11-12): provides that: "Although their impact depends on the types of platform concerned and their market power, some platforms can control access to online markets and can exercise significant influence over how various players in the market are remunerated. This has led to a number of concerns over the growing market power of some platforms. These include a lack of transparency as to how they use the information they acquire, their strong bargaining power compared to that of their clients, which may be reflected in their terms and conditions (particularly for SMEs), promotion of their own services to the disadvantage of competitors, and non-transparent pricing policies, or restrictions on pricing and sale conditions.

Some online platforms have evolved to become players competing in many sectors of the economy and the way they use their market power raises a number of issues that warrant further analysis beyond the application of competition law in specific cases".

The activities of the European and national Authorities, analysed above, are aimed at promoting the competitive effects of the comparison websites through the issue of rules that make the activity of intermediaries "transparent" and such as to provide consumers with truthful and understandable information. But, on the opposite side, if we consider the potential impact of the sites in relation to collusive behaviour, transparency can become a feature that facilitates this type of behaviour.

In fact, markets are typically more vulnerable to collusive behaviour when business initiatives can be viewed in a timely and credible manner by competitors. This is more likely when information provided to clients is transparent, such as in a digitized market, where greater transparency allows to anticipate others' moves and to quickly calculate their consequences and to decide strategies to punish deviations and to support parallel behaviour.

"In markets where customers can switch easily between suppliers and where the goods are homogenous, computer algorithms can quickly detect price reductions by a rival and effectively deprive the rival of any significant sales. The greater the price transparency, the quicker the competitive response, the less likely the first-mover will benefit, and the less likely the price reduction" (Ezrachi e Stucke 2015, p. 19)

In general, online platforms can be useful tools for a potential cartel: for example, platforms can be used to exchange sensitive business information or collude with innovative and even less detectable tools. In fact, through a platform, companies can very easily send signals to their competitors and monitor their reactions to these signals with consequent significant risks of tacit pricing. And, once there is a price-fixing agreement, it is much easier for the parties to perpetuate the agreement as the behaviour of deviation from the agreement is more evident (Baranes and Cosnita-Langlais, 2016).

In reality, many price-fixing cartels dissolve because of the economic incentives for a cartel enterprise to deviate, selling at a price below that of the cartel. The comparative websites then provide a mechanism to monitor the prices of the members of the cartel and possibly to choose to increase the market price given the fact that the agreement will most likely survive for a long time.

The ability of an online platform to act as a facilitator of a concerted practice, such as that of common pricing, has been highlighted in the Eturas case.

In this case, decided by the Lithuanian Competition Authority in 2012 and later confirmed by the Court of Justice of the European Union on 21 January 2016 (European Court of Justice, Case C-74/14, Eturas UAB e a./ Lietuvos Respublikos konkurencijos taryba), several travel agencies have been sentenced to pay fines for having concluded anti-competitive practices through a common booking online system. The travel agencies purchased by contract from Eturas a license to use a software that allowed them to offer and sell their travels through their website, following a uniform and established way of presenting the booking.

According to the Competition Authority, the anti-competitive practice began on the day the software administrator, via the internal messaging system of that software, sent a message concerning the 
reduction of the discount for Internet travel bookings, following of which the systematic limitation of this discount rate had been implemented in the context of the use of this system by travel agents.

The Authority concluded that the behaviour of the agencies in the relevant market should be seen as constituting a concerted practice, considering that, although Eturas did not operate in the market concerned, it played a role and facilitated that practice. The European Court of Justice confirmed this decision by stating that: "Article 101(1) TFEU must be interpreted as meaning that, where the administrator of an information system, intended to enable travel agencies to sell travel packages on their websites using a uniform booking method, sends to those economic operators, via a personal electronic mailbox, a message informing them that the discounts on products sold through that system will henceforth be capped and, following the dissemination of that message, the system in question undergoes the technical modifications necessary to implement that measure, those economic operators may - if they were aware of that message - be presumed to have participated in a concerted practice within the meaning of that provision, unless they publicly distanced themselves from that practice, reported it to the administrative authorities or adduce other evidence to rebut that presumption, such as evidence of a systematic application of a discount exceeding the cap in question" (European Court of Justice, 2016).

An online platform can therefore be an information exchange tool and this behaviour can be considered as a facilitating practice to support collusion. In truth, for about fifty years there has been debate about the anti-competitive nature of the exchange of information and this discussion has some peculiarities in the case of the insurance market, for which since 1992 there is an exemption for certain categories of agreements and concerted practices that is about to be reviewed (Porrini, 2004 and 2016).

In the Lithuanian Eturas case, the relationship between the comparison website and the comparative companies revealed to be relevant.

In this sense, the comparative website could only play a function of "aggregator" of the offers of companies and then it would be a mere tool used for the exchange; or it could also perform consultancy functions with respect to data processing and use, thus becoming a third party responsible for the exchange; or again the comparator site could be a distributor and direct seller of the policies and, as a subject operating in the market, be one of the parties directly involved in the exchange.

The case of the exchange of information connected with comparison websites could therefore be configured in different ways and, in the absence of a specific regulation, would be difficult to be identified by the Competition Authorities.

Conclusion. The comparison websites constitute an innovation in the distribution of insurance products and, from the point of view of regulation, are under observation in their different configurations and for the consequent effects in a market characterized by a digitalization process.

We have seen how the national and European Community Authorities are in the direction of making the activity of innovative intermediaries, i.e. comparison website, "transparent" and such as to provide consumers with truthful and understandable information.

The possibility of comparing the policies of different companies has advantages for the competitiveness of the market, but may also also have negative effects and there is a strong risk that insurance companies consider the new distributional channel as a tool to implement common strategic behaviours through exchanges of information.

For all these reasons, that have been examined in the article, a specific regulation is requested to control the behaviour of the comparison websites in such a way to have benefits to the markets functioning.

Baranes E., Andrea Cosnita-Langlais A. (2016), The digital economy, a challenge to competition policies, special issue of Réalités Industrielles, August.

Brown J.R., Goolsbee A. (2002), Does the Internet Make Markets More Competitive? Evidence from the Life Insurance Industry, in Journal of Political Economy, Vol. 110, No. 3, pp. 481-507. 
Competition \& Markets Authority (2017), Digital Comparison Tools Market Study, London, 28th March.

EIOPA (2014), Report on Good Practices on Comparison Websites, CCPFI-13/100, 30 January.

European Commission (2015a), GREEN PAPER on retail financial services. Better products, more choice, and greater opportunities for consumers and businesses, Brussels, 12.10.2015, 630 final

European Commission (2015b), "Communication from the commission to the European parliament, the council, the European economic and social committee and the committee of the regions a digital single market strategy for Europe", Brussels, 6.5.2015 192 final.

European Court of Justice (2016), Judgment of the Court (Fifth Chamber), 21 January 2016.

Ezrachi A., Stucke M.E. (2015), Artificial Intelligence \& Collusion: When Computers Inhibit Competition, The University of Oxford Centre for Competition Law and Policy, Working Paper CCLP (L) 40.

Insurance Europe (2017), Europe in Figure - Data 2016, December 2017.

IVASS (2014), Indagine sui siti comparatori nel mercato assicurativo italiano, novembre.

Marano P. (2016), The EU Regulation on Comparison Websites of Insurance Products, in P. Marano et al. (eds.), The "Dematerialized" Insurance, Springer, pp. 61-80

Parcu P.L., Stasi M.L., Botta M. (2016), Antitrust Enforcement in Traditional v. Online Platforms, ENTraNCE Policy Brief 2/2016, published by Robert Schuman Centre for Advanced Studies of the European University Institute.

Porrini D. (2004), Information exchange as collusive behaviour: evidence from an antitrust intervention in the Italian insurance market, The Geneva Papers of Risk and Insurance - Issue and Practice, vol. 29, n. 2, April, pp. 220-234

Porrini D. (2016), Which Consequences in the Insurance Market for the End of the Block Exemption?, Rivista Italiana di Antitrust I Italian Antitrust Review, Vol. 3, N. 2, pp. 160-173.

Д. Порріні, Ph.D., доцент, Університент де Салєнто (Лечче, Італія)

Вплив інновацій на ринкову конкуренцію: на прикладі веб-сайтів для порівняння страхових компаній

На страховому ринку використання цифрових технологій, що полегшують онлайн-транзакції, набуває дедалі більшого масштабу по мірі розповсюдження так званих веб-сайтів для порівняння страхових компаній. Враховуючи вищезазначене, в статті проведено аналіз процесу цифровізації каналів каналів просування страхових послуг як в сфрерах страхування життя, так і в інших секторах страхування в країнах Європейського Союзу. 3 огляду на використання страховими компаніями різноманіття каналів просування страхових послуг (через брокерів, агентів, через механізми банківського страхування тощо), обгрунтовано доцільність використання сайтів, що спеціалізуються на порівнянні страхових компаній. В статті обгрунтовано, що для покращення процесу порівняння страхових компаній та підвищення прозорості інформації, доступної для громадськості через такі інтернет-платформи, необхідним є застосування цілого ряду регуляторних обмежень на європейському страховому ринку. Вплив державного регулювання на ці процеси автор ілюструє на прикладі - італійського законодавства у сфрері страхового нагляду та антимонопольного регулювання. Наукова новизна проведеного дослідження полягає в обгрунтуванні впливу веб-сайтів для порівняння страхових компаній на рівень конкуренції на страховому ринку. Цей вплив в статті описується з одного боку, - як позитивний, що проявляється у зменшенні рівня асиметрії інформації для страхувальників, з іншого - як негативний, що проявляється у сприянні недобросовісній поведіниі (змові) страховиків. Підтвердженням того, що такі онлайн-платформи можуть бути інструментом недобросовісного обміну інформацією, що створює можливість для ринкової змови, є рішення антимонопольного органу Литви, затверджене Європейським судом. В результаті дослідження визначено найбільш ефективні регуляторні інтервенції, застосування яких буде спрямоване на поширення нових каналів просування послуг на страховому ринку. Зокрема, подальше розповсюдження веб-сайтів для порівняння страхових компаній створюватиме передумови для прийняття нових регуляторних обмежень, спрямованих на захист інтересів споживачів та обмеження можливостей недобросовісної поведінки самих страхових компаній.

Ключові слова: страховий ринок, веб-сайти порівняння, регулювання, конкуренція. 